\title{
Velumousspora, a megaspore genus from the Namurian of northern England
}

\author{
EDWIN SPINNER \\ Department of Geology, University of Sheffield, Mappin Street, Sheffield, S1 3JD, England
}

\begin{abstract}
A new megaspore genus Velumousspora is described from Namurian (Stenozonotriletes triangulus-Rotaspora knoxi (TK.) concurrent range zone ( $\mathrm{E}_{2 \mathrm{a}}-\mathrm{E}_{2} \mathrm{~b}$ (pars) goniatite zonation) sediments from the Stainmore outlier, northern England.
\end{abstract}

\section{INTRODUCTION}

The megaspores described below were obtained from a sample of carbonaceous shales outcropping in the Mousegill Beck section of the Upper Carboniferous outlier of Stainmore, Westmorland. Stratigraphically the horizon sampled lies a few metres above the Stricegill Grit and Stricegill Limestone described by Owens \& Burgess (1965, p. 21). Earlier palynological work by Owens (op. cit., p. 32) reported miospore assemblages from these shales indicating an $\mathrm{E}_{2}$ age. More recently, Owens (Owens et. al., 1977, p. 389, pl. 19) described the miospore assemblages as being characteristic of the Stenozonotriletes triangulus-Rotaspora knoxi (TK) concurrent range zone, defined on palynological evidence.

The shale sample was prepared for study using standard techniques. The mineral matter was removed using hydrochloric and hydrofluoric acids. Oxidation of the remaining organic residue was carried out using Schulze's solution (10 minutes) followed by dilute potassium hydroxide solution $(2 \%)$. The megaspore assemblage obtained was varied, but apart from the form described below, the remainder were insufficient in number to warrant description at the present time. Further work is in progress in isolating more material and will be reported later.

The description given below is based mainly on study using transmitted light, the specimens being mounted in a hydrous medium. Some specimens were prepared for scanning electron microscope study (S.E.M.) as an aid in the interpretation and illustration of the morphology. The holotype and illustrated paratypes are stored in the reference collections, Micropalaeontology Laboratory, Geology Department, University of Sheffield.

\section{SYSTEMATIC DESCRIPTIONS}

Genus Velumousspora gen. nov.

Type Species. Velumousspora owensii sp. nov.

Derivation of Name. After the form of the outer layer of the spore wall and the first record of the spore from shales in the Mousegill Beck section.

Diagnosis. Small trilete megaspores approximately circular in outline consisting of three layers forming the spore wall. The middle layer, forms a distinct, laevigate 'central body' with a \pm distinct trilete mark of simple suturae. The outer layer is characterised by closely spaced folds or plications and extends beyond the equatorial margin of the 'central body'. This layer appears less dense (light colour) than the 'central body' and small verrucate-rugulate elements may be present, especially apparent at the margin. The two layers appear only to be in any contact in the area of the trilete mark of the 'central body'. No convincing trilete structure is seen on the outer layer of the spore wall of most specimens, although on some, folds or ridges occur which may represent or simulate a trilete mark. No curvaturae or contact areas are distinguishable either on the outer layer or on the central body. On some specimens a further layer can be distinguished within the 'central body'.

Remarks. The presence of two, in some instances three, distinct layers of material forming the wall of entire specimens presents problems of interpretation and use of nomenclature for the different layers. It is tempting to consider the outermost layer of the wall as being a perispore or perisporial as Dijkstra (1946, p. 3) considered the outermost layer of the wall of Triangulatisporites Potonié \& Kremp, 1954 to be. If it is accepted that a perispore is developed at a late stage in spore maturation, perhaps after the separation of the spore mother-cell, the absence of a distinct trilete structure on the outer layer would support such an interpretation. However, many workers have expressed uncertainty on the question of a perisporial layer being present in fossil material, e.g. Erdtman (1969) suggested the use of a neutral term sclerine; Pokrovskaya (1950) (see also Kremp, 1965) claimed it is usually decomposed in the fossil condition; Harris (1955) pointed out the need for reference to the ontogeny of the spore (impossible in the fossil condition) and Grebe (1971) recommended that 
the term should not be used in the description of fossil material. At the present time I favour the view expressed by Krutzsch (1959) that it is more useful to speak of an outer, middle and inner layer.

The separation of the outer layer from the middle layer is clearly indicated by the folding due to compression of both layers. In addition I have been able to peel the outer layer from the 'central body' using a finely pointed needle and scalpel. Specimens where the outer layer has been removed could be assigned to Calamospora Schopf, Wilson and Bentall 1944, and such specimens, together with others, where the outer layer has been partly removed, were found in the organic residue.

Velumousspora is similar to Triangupapillaesporites Spinner, 1982 in size and in the possession of a threelayered spore wall. The middle layer in both instances forming a 'central body'. However, Triangupapillaesporites is characterised by the presence of papillae on the 'central body' and lacks the plicated outer layer of the spore wall. Granulamembranispora Spinner, 1983 is similar in form and shape to Velumousspora but it lacks the dense plications on the outermost layer of the spore wall.

\section{Velumousspora owensii sp. nov.}

$$
\text { (Pl. 1, figs. 1-7) }
$$

Derivation of Name. Named in honour of Dr. B. Owens, palynologist, Institute of Geological Sciences, Great Britain, who introduced the writer to the material.

Holotype. PI. 1, fig. 1, slide No. M21513, stored in the reference collection, Micropalaeontology Laboratory, Geology Department, Sheffield University.

\section{Description.}

Size and Shape: Small trilete megaspores, circular to oval in compressed outline, originally spherical in shape, varying between $420 \mu$ and $910 \mu$ in maximum diameter ( 30 entire specimens, measured in a hydrous medium), mean $570 \mu$. A distinct 'central body' can be distinguished, circular to oval in outline, sometimes folded, varying between $205 \mu$ and $535 \mu$ in maximum diameter, mean $320 \mu$ (based on 30 specimens measured in a hydrous medium). External to the 'central body' is a Jayer of the spore wall which extends beyond the margin of the 'central body', irregular in outline due to compressional folding. On damaged specimens this surrounding layer may be partially removed.

Haptotypic Structures: The most distinctive evidence of the trilete mark is seen on corroded specimens where three simple suturae can be seen on the 'central body' (see Pl. 1, figs. 1, 4). On the holotype, the suturae are approximately $150 \mu$ in length, straight to slightly curved in outline. On entire specimens the trilete mark is \pm distinct. On some specimens (viewed by reflected light or S.E.M.) ridges can be seen which may represent the position of the trilete mark (see Pl. 1, fig. 6). The positions of the contact areas and curvaturae are not clearly defined.

Exine Structure and Ornamentation: The spore wall consists of three layers, although in some specimens only the two outer layers can be distinguished. The outer layer is characterised by closely spaced folds or plications and has a verrucate-rugulate type of ornament. Elements measured vary between $6 \mu$ and $30 \mu$ in maximum diameter. At the margin the tops of the elements appear rounded. The elements are densely spaced and may simulate a vermiculate pattern. The middle layer of the spore wall forms the 'central body' of the spore. This layer appears darker in colour (denser) than the outer layer, is laevigate and is approximately $25 \mu$ thick (as measured in optical section). The middle and outer layers appear to be in contact in area of the trilete mark on the 'central body'. On some specimens a further layer can be distinguished within the 'central body', thin and folded.

Remarks. The nature of the relationship of the outer layer of the spore wall to the 'central body' is problematical. If it is accepted that the outer layer is not perisporial, then the characters of the outer layer simulate in many respects a velum, as defined by Couper \& Grebe

\section{Explanation of Plate 1 \\ All figures illustrated by transmitted light unless stated otherwise. Slides are stored in the reference collection, Micropalaeontology Laboratory, Geology Department, Sheffield University.}

Figs. 1-7, Velumousspora owensii sp. nov.

Fig. 1 Holotype. Slide ML1513 ( $\times 100)$.

Figs. 2-3 Part of outer layer of spore of holotype, illustrating ornament and plications $(\times 400)$.

Fig. 4 Part of holotype, illustrating smooth central body, suturae and inner layer of spore wall $(\times 400)$.

Fig. 5 Paratype. Slide ML1514 $(\times 100)$.

Fig. 6 Paratype. (S.E.M.) $(\times 100)$.

Fig. 7 Part of specimen illustrated in fig. 6, illustrating plications of outer layer of spore wall $(\times 500)$. 

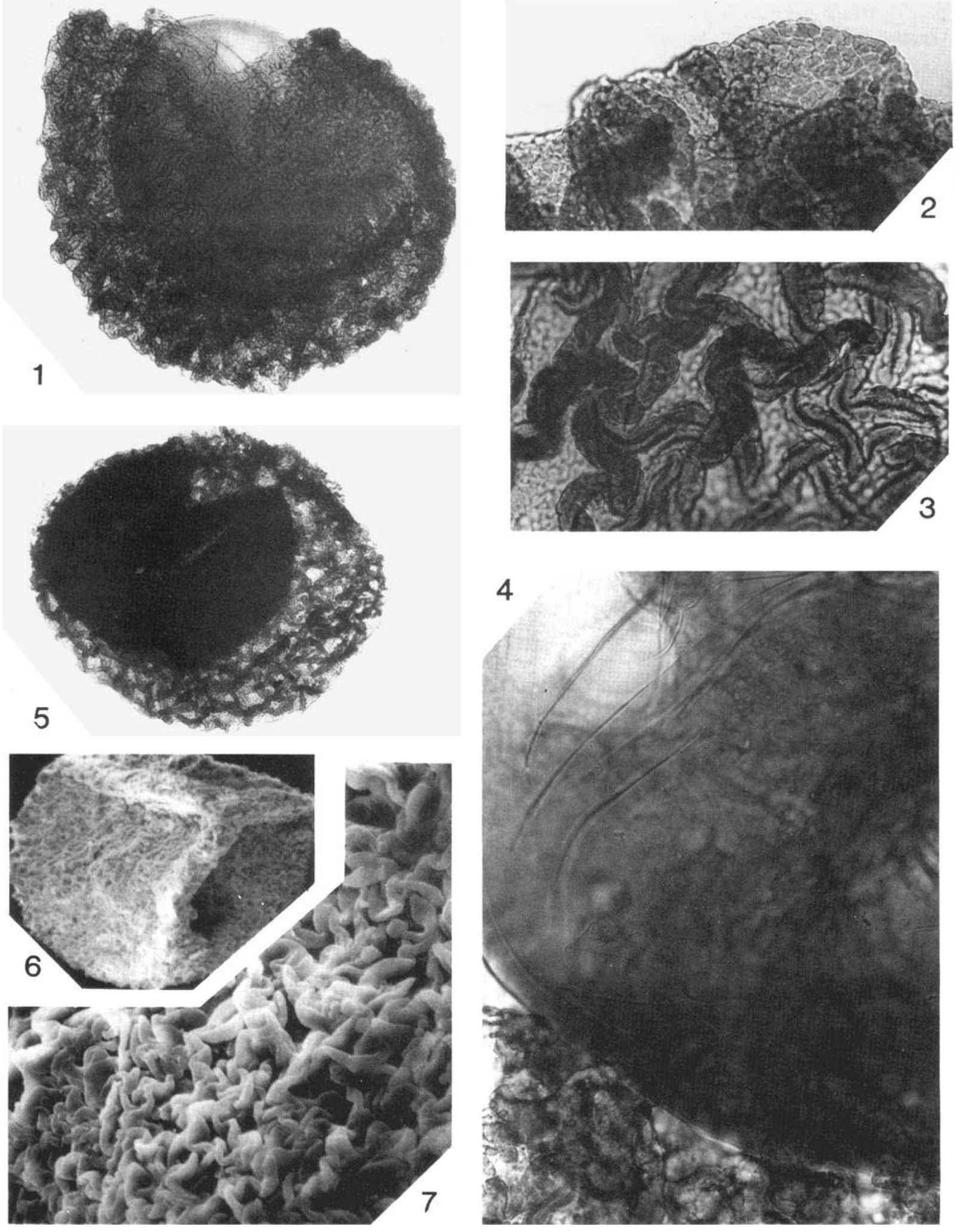
(1961, p. 5). However, Grebe later (1971, p. 16) redefined the term with emphasis on "multiple points of contact between the exine layers" which, in view of the relative ease by which the outer layer separates cleanly from the central body, casts doubts on such an interpretation being made. Neves \& Owens $(1966$, p. 339) introduced the term 'camerate' for separation of layers within spore walls, but these authors were concerned with spores in which only two layers were recognised, for which they used the terms 'intexine' and 'exoexine'. In the present instance it is probably most acceptable to use the term 'cavate' as employed by Harris (1955, p. 25) indicating a separation of the outermost layer of the spore wall.

$V$. owensii sp. nov. resembles Triangupapillaesporites biseratus Spinner, 1982 in overall size and in having a three layered spore wall, but the outer layer of $V$. owensii is different to $T$. biseratus in being highly plicated or folded and the 'central body' lacks the biserially arranged papillae which characterises $T$. biseratus. Granulamembranispora dodgesontownii Spinner, 1983 is similar in form to $V$. owensii, but the outer layer of the spore wall lacks the plications which characterise $V$. owensii.

\section{REFERENCES}

Burgess, I.C.\& Holliday, D.W. 1979. Geology of the country around Brough-under-Stainmore. Mem. Geol. Surv. G.B., Sheet $31,131 \mathrm{pp}$.

Couper, R.A. \& Grebe, H. 1961. A recommended terminology and descriptive methods for spores. Compte Rendu III Reunion de la Commission Internationale de Microflore du Paleozoique, Krefeld, Report Group 16, 15 pp.

Dijkstra, S.J., \& Vierseen Tripp, P.H. van. 1946. Eine monographische Bearbeitung der Karbonischen Megasporen mit besonderer Berucksichtigung von Sudlimburg (Niederlande). Med. Geol. Stichting, ser. C-111-1, $101 \mathrm{pp}, 16 \mathrm{pls}$.

Erdtman, G. 1969. Handbook of Palynology. 486 pp. Hofner Publishing Co. Inc. New York, U.S.A.

Grebe, H. 1971. A recommended terminology and descriptive method for spores. Publications de la Commission Internationale de Microflore du Paléozoique No. 4, Centre National de la Recherche Scientifique, Paris, 34 pp.

Harris, W.F. 1955. A manual of the spores of New Zealand Pteridophyta. A discussion of spore morphology and dispersal with reference to the identification of spores in surface samples and as micro-fossils. Dept. Scientific and Industrial Research, New Zealand, Bull. I16, 186 pp.

Kremp, G. 1965. Morphologic Encyclopedia of Palynology. Contribution 100, Program in Geochronology, University of A rizona. Tucson. The University of Arizona Press, Tucson, 185 pp., 38 pls.

Krutzch, W.K. 1959. Mikropalaontologische (sporenpalanontologische) Untersuchungen in der Braunkohle des Geiseltales. Goologie Jahrgang 8, 425 pp., 49 pls.

Neves, R. \& Owens, B. 1966. Some Namurian camerate miospores from the English Pennines. Pollen et Spores, VIII, 3.37-360, 3 pls.

Neves, R., Gueinn, K.F., Clayton, G., Ioannides, N.S. \& Noville, R.S.W. 1972. A scheme of miospore zones for the British Dinantian. Compte Rendu 7 me Congr. Int. Stratigr. Geol. Carbonif. Krefeld, 1, 347-353.

Owens, B. \& Burgess, I.C. 1965. The stratigraphy and palynology of the Upper Carboniferous outlier of Stainmore, Westmorland. Bull. geol. Surv. (B.B., London, 23, 17-44.

Owens, B., Neves, R., Gueinn, K.J., Mishell, D.R.F., Sabry, H.S.M.Z. \& Williams, J.E. 1977. Palynological division of the Namurian of Northern England and Scotand. Pres. Yorks. geol. Soc., 41, 381-98, pls. 18-19.

Pokrovskaya, I.M. 1950. Pollen analysis. Gosgeolisdat 57 I pp., 17 pls. (in Russian).

Potonié, R. \& Kremp, G. 1954. Die Gattungen der Palaozoischen Sporac Dispersac und ihre Stratigraphic. Cied. Jahrbuch, 69, 111-194, 17 pls.

Schopt, J.M., Wilson, L.R. \& Bentall, R. 1944. An annotater synopsis of Palaeozoic fossil spores and the definition of generic groups. Illinois Geol. Surv. Report, Investigation 91. $72 \mathrm{pp}$.

Spinner, F. 1982. A new megaspore genus from the Lower Carboniferous (Asbian) of northern England. I. micropalaeontol., I ondon, 1, 19-22, $1 \mathrm{pl}$.

Spinner, E. 1983. In press. Some new sporomorphs from the lower Carboniferous of N.W. England. Pollen ef Spores. XXV, $117-129,4$ pls. 